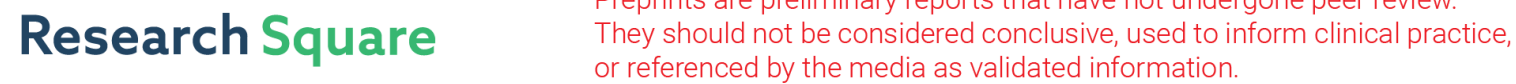

\section{Enhancement of microbial fuel cell performance by anodic communities adaptation and cathodic mixed nickel copper oxides ( $\mathrm{NiO}-\mathrm{CuO}$ ) on graphene electrocatalyst}

\author{
Dena Z Khater \\ National Research Centre \\ Rabab S Amin \\ National Research Centre \\ Monera O Zhran \\ Al-Azhar University \\ Zeinab K Abd El-Aziz \\ Al-Azhar University \\ Mohamed Mahmoud \\ National Research Centre \\ Helmy M Hassan \\ National Research Centre
}

Kamel M El-Khatib ( $\sim$ kamelced@hotmail.com )

National Research Centre https://orcid.org/0000-0002-0608-7464

Research Article

Keywords: Microbial fuel cell, NiO-CuO/G, Linear Sweep Voltammetry, Electrocatalyst, Activated Sludge

Posted Date: April 26th, 2021

DOI: https://doi.org/10.21203/rs.3.rs-405277/v1

License: (c) (i) This work is licensed under a Creative Commons Attribution 4.0 International License. Read Full License 


\section{Abstract}

Mixed transition metal ( $\mathrm{Ni} \& \mathrm{Cu}$ ) oxides supported on graphene (NiO-CuO/G) electrocatalyst was fabricated and tested as an efficient and cost-effective cathode for oxygen reduction reaction (ORR) in microbial fuel cells (MFCs). The electrocatalytic activity and selectivity of the NiO-CuO/G for ORR were examined using linear sweep voltammetry measurements (LSV) on a rotating disc electrode (RDE) in pH-neutral electrolyte. In comparison with a benchmark platinum cathode, the NiO-CuO/G showed high selectivity towards the ORR. The analysis of Koutecky-Levich relationship suggests that the electrocatalyst follows the four-electron ORR pathway. NiO-CuO/G cathode in an air-cathode MFC exhibited a slightly lower power density $21.25 \mathrm{mWm}^{-2}$ compared to 50.4 $\mathrm{mW} \mathrm{m}{ }^{-2}$ for Pt/C. Both scanning and transmission electron microscope analyses of anodic biofilm showed that a thick biofilm was successfully developed with a rod-like shape. Biochemical characterization of the communities showed that four genera named Escherichia coli (E-coli), Shewanella putrefaciens, Bacillus cereus and Bacillus Thuringiensis/mycoides, which belonging to GammaProteobacteria and Firmicutesphylathatwerethe most abundant bacteria in the anodic biofilm. Our results revealed that $\mathrm{NiO}-\mathrm{CuO} / \mathrm{G}$ cathode demonstrates an enhanced electrocatalytic activity toward ORR in a pH-neutral solution; thus, the newly developed mixed transition metal oxides electrocatalyst can replace other expensive Pt-based catalysts for MFC application.

\section{Introduction}

Microbial fuel cell (MFC) is an anaerobic biotechnology system that has the ability to convert the chemical energy stored in waste streams to electricity (E.Logan 2008; Wang, H., and Ren 2013). A commonly used low-cost design is air-cathode, single-chamber MFC, which lacks an ion exchange membrane that separates anode and cathode chambers without the need of external aeration in the cathodic chamber. Compared to other MFC configurations, air-cathode MFC is considered a promising option for wastewater treatment owing to the availability and high redox potential of electron acceptor (i.e., natural air) (Youngho 2013).The bioelectrochemical reactions for electricity generation in MFCs involve an oxidation reaction of organic matter in the anode chamber and a reduction reaction of an electron acceptor (ideally is oxygen) in the cathode chamber. The hallmark of an MFC is the ability of electroactive biofilm(known as electricigens or anode-respiring bacteria) to oxidize organic matter and respire the resulting electron to the anode surface, and simultaneously protons $\left(\mathrm{H}^{+}\right)$ move into electrolyte, leading in a negative anode potential. This sticky biofilm matrix consists of extracellular protein, sugar, and bacterial cells complex. In the course of the cathodic reaction, the protons are transferred to the cathode through the electrolytes while the electrons are transferred to the cathode via an external circuit (Lefebvre et al. 2012; Valipour et al. 2016).

Despite the growing interests in MFCs over the past few decades, they are often characterized with low power and current densities, which hinder its scaling-up (Herna'ndez-Ferna'ndez, F.J., Pe'rez de los Ríos, A. et al. 2015; Vogl, A., Bischof, F., and Wichern 2016). The main cause for this low efficiency is probably due to low kinetic rate of oxygen reduction reaction (ORR) in the neutral $\mathrm{pH}$ aqueous electrolyte that requires high activation energy to split the $\mathrm{O}=\mathrm{O}$ bond, which about $498 \mathrm{kJmol}^{-1}$ (Wang et al. 2014). Consequently, the modification of electrode materials using highly effective ORR electrocatalystsis crucial for enhancing the efficiency of MFCs (Yan et al. 2012). Although Platinum (Pt) has been commonly used as a electrocatalyst to decrease the cathodic overpotential in MFCs due to its high electrocatalytic activity towards ORR (Rozendal et al. 2008), its practical applications have been restricted by its high cost, low stability during long-term operation, and its rare availability(Li et al. 2016; H. A. Gasteiger, S. S. Kocha 2005). Over the past decade, several studies have been focused on replacing expensive Pt electrocatalysts with cost-effective, non-precious metal oxides electrocatalysts. Pt-free transition metals oxides, such as Co, Fe and Mn-based electrocatalysts have gained increasing attention, owing to their durability, high performance, and relatively low-cost (Zhang et al. 2014). For example, the introduction of metal element or metallic oxide, such as Fe (Anon n.d.), CoTMPP (Sun 2012), MnOx (R. Burkitt, T. Whiffen 2016),

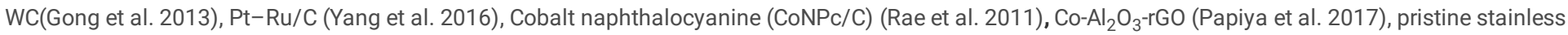
steel mesh/cobalt oxide $\left(\mathrm{SSM} \mathrm{CO}_{3} \mathrm{O}_{4}\right.$ ) (Gong et al. 2014), Pt-Co alloy nanoparticles on graphene (Pt-Co/G) (Yan et al. 2013) and Copper phthalocyanine (CuPc) were used as alternative electrocatalysts for enhancing the MFC performance (Ghasemi et al. 2013).

The use of transition mixed metal oxides composites as cathode electrocatalysts led to higher electrocatalytic enhancement activities, through which one metal breaks the $\mathrm{O}=\mathrm{O}$ bond of molecular $\mathrm{O}_{2}$, and then the adsorbed atomic oxygen atoms migrate to the other metal, where the electro-reduction step takes place (Lima et al. 2006). Compared to other non-noble metal, nickel remains one of the most widely used metal in the realm of electrochemistry due to its availability, its high efficiency as an electrocatalyst (Kartick et al. 2016), its lower hydrogen evolution reaction (HER) overpotential, and its high stability under harsh conditions (Manuel MF, Neburchilov V, Wang H, Guiot SR 2010; Hu H, Fan Y 2010). Both nickel and copper have a low price (0.02 and 0.007 USD/g, respectively) compared to noble metal catalysts (e.g. Pt: $26.5 \mathrm{USD} / \mathrm{g}$ ) according to a recent quotation and information extracted from (www.kitco.com). On the other hand, Cu-based electrocatalyst exhibit biomimetic chemistry with $\mathrm{O}_{2}$, such as the reductive activation $\mathrm{O}_{2}$ in enzymes and the protein laccase (Jahan et al. 2013).In addition, support materials are essential to disperse electrocatalyst particles and prevent their self-aggregation, leading to improve the performance of MFC. In this regard, graphene is usually used as an electrocatalyst support because of its large specific surface, its high electrical conductivity with low internal resistance, and high chemical stability and anti-corrosion (Shaari, N., and Kamarudin 2017). In addition, it possesses abundant functional groups on the surface, which provides the accessible active sites.

In this study, we explored the feasibility of $\mathrm{NiO}-\mathrm{CuO} / \mathrm{G}$ as a cathode electrocatalyst in MFCs due to its low price and high efficiency. To the best of our knowledge, there are no reports that investigated the use of transition mixed metals oxides (NiO-CuO/G) composites as alternative electrocatalysts in MFCs. It would develop a potential prospect of the NiO-CuO/G composite electrocatalyst for enhancing the MFC efficiency. First, the as-prepared electrocatalyst was characterized by using X-ray powder diffraction (XRD), transmission electron microscopes (TEM), scanning electron microscopes (SEM), and X-ray energy dispersive spectrometer (EDX). Second, the ORR kinetics and mechanisms was carried out using rotating disk electrode (RDE). Third, the electrochemical performance in MFC was evaluated and compared to a benchmark cathode (i.e., Pt/C) in an MFC. Finally, the surface morphology of bioanode was visualized by SEM and TEM, and the biochemical properties of isolated anodic strains were identified using the vitek2 compact system method.

\section{Materials And Methods}




\subsection{Chemicals}

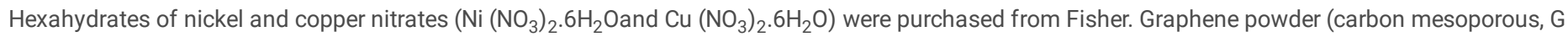
average pore diameter $100 \mathrm{~A}^{0}$, typical $>99.95 \%$ trace metal, graphitized carbon black) and $5 \mathrm{wt} . \%$ Nafion solutions were purchased from Sigma-Aldrich (MO, USA). Pt on carbon Vulcan (30\%Pt/C, Etek) electrocatalyst was obtained from Fuel cell store (TX, USA). All Supplies and chemical materials were of analytical grade purity and used as obtained without further purification. All aqueous solutions were newly prepared throughout the experiments with de-ionized distilled water (DI).

\subsection{Synthesis of NiO-CuO/G electrocatalyst}

The used mixed metals oxides composite of $\mathrm{NiO}-\mathrm{CuO} / \mathrm{G}$ was prepared using a co-precipitation method. The mixed metal salts precursors of $\mathrm{Ni}$ $\left(\mathrm{NO}_{3}\right)_{2} \cdot 6 \mathrm{H}_{2} \mathrm{Oand} \mathrm{Cu}\left(\mathrm{NO}_{3}\right)_{2} \cdot 6 \mathrm{H}_{2}$ Owere dispersed on a high surface area of graphene $(\mathrm{G})$ in ultrapure deionized water. In a typical synthesis, the pH value (Adwa $\mathrm{AD} 1000 \mathrm{pH} / \mathrm{mV}$ \&temp meter) of this mixture was adjusted approximately 10 by drop-wise addition of $1 \mathrm{M} \mathrm{NaOH}$ solution followed by constantly stirring (Wise stir MSH-20 OD) for 3 hours to avoid agglomeration and obtain a homogenous dispersion. Subsequently, the resulting black precipitate of metal hydroxide was then filtered and washed with $100 \mathrm{ml} \mathrm{DI}$ water several times to adjust its $\mathrm{pH}$ at 7.After that, the drying process for the resulting final product was carried out at $80{ }^{\circ} \mathrm{C}$ in a TiTANOX dryer for 6 hours to remove the excess of water. The dried precipitate was then calcinated for 3 hours under $300^{\circ} \mathrm{C}$ in $\mathrm{SHIN}$ SAENG muffle furnace to form oxide. The corresponding mass ratio in the obtained NiO-CuO/G was $30 \%$ to $70 \%$ of G.

\subsection{Electrochemical measurements using a rotating ring-disk}

The electrochemical measurements were performed at room temperature $\left(25 \pm 1^{0} \mathrm{C}\right)$ using the Voltamaster 6 potentiostat (PST006) and rotating disk electrode (RDE, CTV 101 speed control unit) apparatus. The working electrode (with a geometrical surface area $0.196 \mathrm{~cm}^{2}$ ) was either NiO-CuO/G or Pt/C deposited on the surface of glassy carbon (GC) disk electrode, while Pt wire and a commercial Ag/AgCl (Metrohm) were used as a counter and a reference electrode, respectively. Prior to depositing catalyst layer on GC disk electrode, GC electrode was first polished mechanically using $0.05 \mu \mathrm{m}$ alumina slurry and a soft cloth to obtain a mirror-like surface. Finally, GC electrode was rinsed with DI water and acetone. Following that, $1 \mathrm{mg}$ of the electrocatalyst was sputtered and mixed with one droplet of isopropanol on the polished GC. After drying of isopropanol on the glassy carbon disk surface, one droplet of a diluted Nafion solution (5\%) was pipetted to attach the catalytic particles on the RDE electrode substrate and form a homogeneous ink. Finally, a second droplet of isopropanol was added, and the electrocatalyst film was left to dry at room temperature overnight.

The cyclic voltammogram (CV) experiments were conducted in $50 \mathrm{mM}$ phosphate buffer solution ( $\mathrm{PBS}$; $\mathrm{pH}$ value $=7.2)$ saturated with either $\mathrm{N}_{2}$ or $\mathrm{O}_{2}$ at a scan rate of $50 \mathrm{mV} \mathrm{s}^{-1}$. The linear sweep voltammetry (LSV) was conducted with a scan rate of $10 \mathrm{mV} \mathrm{s}^{-1}$ and different rotation speed (0 to $\left.2400 \mathrm{rpm}\right)$ in a potential range of (-1000 to $1000 \mathrm{mV}$ vs. Ag/ $\mathrm{AgCl})$ (-780 to $1220 \mathrm{mV}$ vs. SHE). Prior to performing electrochemical measurements, we sparged electrolyte with UHP oxygen for 30 minutes. For comparison, we performed all electrochemical measurements in nitrogen-saturated PBS. The schematic synopsis of experimental setup was illustrated in Figure S1.

The kinetic parameters were analyzed based on the Koutechy-Levich equation derived from RDE experiments to calculate electron transfer numbers ( $\mathrm{n}$ ) involved in the ORR process (Gong et al. 2013) as follows:

$$
\frac{1}{\mathrm{Id}}=\frac{1}{\mathrm{IK}}+\frac{1}{0.62 \mathrm{nFAD}^{2 / 3} \mathrm{cv}^{-1 / 6 \omega^{1 / 2}}}
$$

$I_{d}$ is the disk current density, $I_{k}$ is the electrode potential-dependent kinetic current density, $\omega$ is the angular momentum (rads ${ }^{-1}$ sec $^{1 / 2}$ ), $n$ is the average number of involved electrons in the catalytic reaction (4 is the maximum), $\mathrm{F}$ is Faraday constant $\left(96,487 \mathrm{C} \mathrm{mol}^{-1}\right)$, $\mathrm{D}$ and $\mathrm{C}$ are the diffusion coefficient of dissolved oxygen $\left(1.9 \mathrm{e}^{-5} \mathrm{~cm}^{2} \mathrm{~s}^{-1}\right)$ and the concentration of dissolved oxygen in $50 \mathrm{mM} \mathrm{PBS}\left(1.117 \mathrm{e}^{-6} \mathrm{~mol} \mathrm{~mL}^{-1}\right)$, respectively, vis the kinetic viscosity of the electrolyte $\left(0.01073 \mathrm{~cm}^{2} \mathrm{~s}^{-1}\right)$, and $A$ is the geometric area of the disk electrode $\left(0.196 \mathrm{~cm}^{2}\right)$ (Rojas-carbonell et al. 2017).

\subsection{Configuration of the MFC}

All MFCs experiments were conducted using single-chamber, air-cathode MFCs $(6 \mathrm{~cm}$ long, $4.6 \mathrm{~cm}$ in diameter, total working volume $=100 \mathrm{ml})$ as described in (Khater et al. 2017) as shown in Figure S2. The anodes were unmodified sheet of three-dimensional carbon felt (not waterproof) glued to the top of the externally connected anode port. They were positioned in the other side of the chamber (perpendicularly to the cathode) at a distance of $5 \mathrm{~cm}$ from the cathode. They had an effective dimension of $2.5 \times 2.5 \times 0.6 \mathrm{~cm}$ and the projected surface area of $18.50 \mathrm{~cm}^{2}$. The gas-diffusion carbon cloth electrodes were used as cathode electrode $\left(6 \times 6 \mathrm{~cm}\right.$ each; surface area of $\left.16.63 \mathrm{~cm}^{2}\right)$ with a catalyst loading of $0.30 \mathrm{mg} / \mathrm{cm}^{2}$. The current collectors (a titanium wire) were put on both sides of the electrodes.

\subsection{Catalyst preparation for MFC cathode fabrication}

We prepared cathode electrodes as described elsewhere (Zeng et al. 2010). The employed catalyst was maintained on the water-facing side of the cathode at a loading of $0.3 \mathrm{mg} \mathrm{cm}^{-2}$. Before coating, the catalyst slurry was prepared by mixing the corresponding content of NiO-CuO/G composites with $5 \%$ Nafion solution. The mixture was ultra-sonicated at $60{ }^{\circ} \mathrm{C}$ for $30 \mathrm{~min}$ and dispersed uniformly onto the carbon cloth surface electrode (mesoporous gas diffusion, 
Fuel cell store, TX, USA). In order to reach the load of the prepared electrode $\left(0.3 \mathrm{mg} \mathrm{cm}^{-2}\right)$ several successive layers were deposited on top of each other. All electrodes were dried at room temperature for 24 hours before its use in MFCs. For comparison, 30 wt.\% of the Pt catalyst supported on carbon Vulcan (BET surface area $220 \mathrm{~m}^{2} . \mathrm{g}$, Etek, USA) was used as a cathode at catalyst loading of $0.3 \mathrm{mg} \mathrm{cm}^{-2}$ using the same procedure as described before.

\subsection{MFC operation and analysis}

The MFCs were inoculated with aerobic activated sludge from a local municipal wastewater treatment plant (Benha, Egypt), and was operated under fed-batch mode of operation for a total 60 days to allow biofilm to grow on the anode surface (Lee et al. 2009). MFCs were fed with artificial wastewater containing: sodium acetate $\left(2 \mathrm{gL}^{-1}\right)$ as the soleorganic substrate in a $50 \mathrm{mM}$ phosphate buffer solution (PBS) (COD concentration $=1472 \pm 17 \mathrm{mg} / \mathrm{L}$ ) amended with $12.5 \mathrm{ml}$ mineral solution and $12.5 \mathrm{ml}$ vitamin solutions. The $50 \mathrm{mM} \mathrm{PBS}$ contained (in grams per liter of de-ionized water): $\mathrm{NaHCO}_{3}, 2.5 ; \mathrm{NH}_{4} \mathrm{Cl}, 0.2 ; \mathrm{KH}_{2} \mathrm{PO}{ }_{4}, 13.6 ; \mathrm{KCl}$, $0.33 ; \mathrm{NaCl}, 0.3, \mathrm{~K}_{2} \mathrm{HPO}_{4}, 17.4, \mathrm{CaCl}_{2} .2 \mathrm{H}_{2} \mathrm{O}, 0.15, \mathrm{MgCl}_{2}, 3.15$, yeast extract 1 ). All MFCs tests were conducted in triplicate for calculating the average value.

MFCs were operated in fed-batch mode at room temperature and their overall potential was monitored using a data acquisition system (Lab jack U6-PRO, USA) connected to a personal computer. An external resistance of $1000 \mathrm{ohm}$ was used unless otherwise stated. The current densities ( $\mathrm{mAm}^{-2}$ ) and power densities $\left(\mathrm{mWm}^{-2}\right)$ were calculated using the Ohm's law as previously described in (Khater et al. 2017; Valipour et al. 2016). The Polarization and power curves were plotted using single-cycle technique by recording the pseudo-steady-state voltage across different external resistances, ranging from $175 \mathrm{k} \Omega$ to $50 \Omega$ in reducing order stepwise (Watson, V.J. \& Logan 2011). The internal resistance $\left(R_{\text {int }}\right)$ was determined using a linear regression corresponding to the ohmic zone on the linear part of the polarization curve (Picoreanu et al. 2007).

The influent and effluent chemical oxygen demand (COD) concentrations were determined and analyzed according to APHA standard method. The organic substance concentration is calculated as COD removal efficiency (COD \%), which is calculated using the following equation (Andrew et al. 1995):

$\operatorname{COD} \%=\left(\left(\mathrm{COD}_{\text {initial }}-\mathrm{COD}_{\text {final }}\right) / \mathrm{COD}_{\text {initial }} \times 100\right)$

The Coulombic efficiency $\left(C_{E}\right)$ was determined by integrating the measured current with respect to the theoretical current based on consumed COD as follows:

$C_{E}(\%)=\left(C_{P} / C_{T}\right) 100$

Where $\mathrm{C}_{\mathrm{T}}$ is the theoretical amount of coulombs production, it was estimated as $\left.\left(\mathrm{C}_{\mathrm{T}}=(\mathrm{F} \times \mathrm{N} \times \mathrm{W} \times \mathrm{V}) / \mathrm{M}\right)\right)$. where $\mathrm{F}=\mathrm{Faraday}$ 's constant $\left(96485 \mathrm{C}\right.$ mol $\left.^{-1}\right), \mathrm{N}=$ no. of moles of electrons ( $\left.8 \mathrm{~mol} \mathrm{~mol}^{-1}\right) \mathrm{COD}, \mathrm{W}=$ daily $\mathrm{COD}$ load removed in gram, $\mathrm{M}=$ molecular weight of acetate $\left(82 \mathrm{gmol}^{-1}\right), \mathrm{V}$ was the medium volume $(0.0001 \mathrm{~L})$ (Feng et al. 2008). $C_{P}$ is the actual current production collected by the anode during one batch cycle was integrated as $\left(C_{P}=I x t\right)$ where $I$ is the produced current, $\mathrm{t}$ is time duration (sec).

\subsection{Physical characterization of NiO-CuO/G and the produced anodic biofilm}

\subsubsection{X-ray diffraction patterns (XRD).}

XRD were performed using XRD-RIGAKU-D/MAX-PC 2500 X-ray diffractometer fitted with Ni-filtered Cu Ka as the radiation source $(\lambda=0.154056 \mathrm{~nm})$ for the determination of physical characteristics such as lattice composition and distinctive crystallite size of NiO-CuO/G electrocatalyst. The current of the tube was $40 \mathrm{~mA}$ with a voltage of $40 \mathrm{kV}$. XRD sample was prepared by fixing the electrocatalyst powder on a glass slide. It was then dried up overnight in the vacuum. The $2 \theta$ angular regions were detected with a scan rate of $10 \circ \mathrm{min}-1$ from $10 \circ$ up to 80 , analysis of XRD data was carried out using the Materials Studio (Accelrys) software suites Reflex module. XRD patterns were indexed using X-Cell in Materials Studio (Accelrys) software.

\subsubsection{Scanning Electron Microscopy (SEM) analysis for electrocatalyst \& biofilm.}

The characterization of anodic biofilm growth were further visualized at the end of our batch experiments using SEM (JEOL JAX-840A) for determining the probability of biofilm formation in the anode electrode surface. The anode was fixed with $2.5 \%(\mathrm{w} / \mathrm{v})$ glutaraldehyde for $4 \mathrm{~h}$. Following the fixation step, the samples were washed with water three times, and dehydrated by successive immersing it in ethanol solutions $(30 \%, 50 \%, 70 \%, 80 \%, 90 \%, 95 \%$ and absolute ethanol; 10 min for each step) in order to avoid drying artifacts. The specimens have then dried, mounted onto SEM specimen holders tubs using graphite paste, and then the specimens were sputtered with gold. Energy dispersive X-ray (EDX) was mapped using a SEM (JEOL JAX-840A).

\subsubsection{Transmission Electron Microscope (TEM) for electrocatalyst \& biofilm.}

JEOL-JEM 2010 TEM at an accelerating voltage of $160 \mathrm{kV}$ was used to determine the microstructure and particles size of the as-prepared NiO-CuO/G, and to understand the internal morphological characteristics of isolated strain. In order to prepare the electrocatalyst specimens for TEM measurement, 2 mg of electrocatalyst powder was dispersed ultrasonically in $2 \mathrm{ml}$ isopropanol in Wise stir MSH-20 OD for 20 min to achieve a uniform catalyst ink. A drop of this suspension was placed on $1 \mathrm{~mm}$ copper grid covered with continuous carbon film and left in the air to dry. TEM analysis procedures for the isolated anodic strain was prepared in a sterilized condition at room temperature $(230 \mathrm{C})$ by inoculation of $100 \mu \mathrm{L}$ bacterial cultures in $5 \mathrm{ml}$ sterilized nutrient broth. The inoculated broth incubated in at $370 \mathrm{C}$ for $18-20$ hours before TEM analysis. Then, samples were fixed in $2.5 \%$ glutaraldehyde (w/v) at $40 \mathrm{C}$ for a few minutes. Before TEM imaging, the harvested bacterial cells were deposited in the TEM grid, stained with $2 \%$ uranyl acetate for 3 to 5 seconds on a carbon-coated mesh copper grid, and dried in the air. Gatan program was used for data processing and particle size measurement (Maruthupandy et al. 2015).

2.7.3 Biochemical identification of isolated anodic bacterial communities by vitek2 compact system method. 
The identification of isolated anodic bacterial communities was done according to the manufacture's instruction (Biomeriux VITEK-2 Compact ref Manual Ref-414532) (BioMe'rieux. 2006). A sufficient amount of anodic biofilm were transferred using a sterile swab, suspended in $3 \mathrm{ml}$ of sterile saline in a $12 \times 75$ $\mathrm{mm}$ polystyrene test tube, and then mix the suspension well. The turbidity was adjusted to the equivalent of a $0.5-0.63 \mathrm{McFarland}$ turbidity using a turbidity meter called VITEK®2 DensiCHEK ${ }^{\mathrm{T}}$. The microorganism suspension was placed into a special rack (cassette) and the identification card was placed in the neighboring slot. The filled cassette was placed into a vacuum chamber station. Data were collected at 15-minute intervals during the entire incubation period to measure either turbidity or colored products of substrate metabolism. A transmittance optical system allows the interpretation of test reaction using different wavelengths in the visible spectrum. In addition, a special algorithm was used to eliminate false reading due to small bubbles that may present. Finally, the results were obtained automatically printed within 10 hours or less. All used cards were automatically dispensed into a waste container.

\section{Results And Discussion}

\subsection{Characterization of NiO-CuO/G}

The crystalline features and structural properties of $\mathrm{NiO}-\mathrm{CuO} / \mathrm{G}$ composite were examined and the findings are displayed in Fig. 1. It can be seen that a sharp and powerful diffraction peak is associated with the $2 \theta$ value of $25.914^{0}$ (002 planes), which can be ascribed to the crystalline nature of the graphite framework support of the electrocatalyst (Papiya et al. 2017). Furthermore, the $C$ (002) peak becomes softer as the metal particles on the graphene fill up the diffraction towards the composites, leading to a graphene peak reduction. There is a mildly wide distinguished diffraction of four primary planes at around peaks $2 \theta$ value of $\sim 43.039^{0}, 54.56^{\circ}, 64.96^{0}, 78.88^{\circ}$ connected with (111), (200), (220) and (311) crystal planes of crystalline structure of NiO and2 $\theta$ value of $35.6^{0}, 38.7^{0}, 48.8^{0}, 58.4^{0}, 74.1^{0}$ be assigned to $(-111),(200),(-202),(202)$ and (220) for CuO. Mixed metal oxides are existing as NiO and CuO, suggesting the effective synthesis of the NiO/CuO composite (He, Y., Chen, W., Li, X., Zhang, Z., Fu, J., Zhao, C., and Xie 2013; Jiang L-C 2010).The representative peaks in Fig. 1 confirm the successful deposition of $\mathrm{NiO}$ and $\mathrm{CuO}$ on graphene (Savy M, Coowar F, Riga J, Verbits JJ, Bronoe" I G 1990). This deposition may be due to the graphene's elevated surface area and conductivity with available part active sites, which enhanced the high bioelectrochemical efficiency of NiO-CuO/G towards the ORR (Ghasemi et al. 2013).

Furthermore, we used TEM to clarify the NiO-CuO/G composite microstructure and deeper surface morphology. Figure 2 illustrates the particle distributions of $\mathrm{NiO}-\mathrm{CuO} / \mathrm{G}$ electrocatalyst. It can be shown that there are large amounts of NiO-CuO metal particles that aggregated with each other along with the graphene to form agglomeration of the prepared electrocatalyst on the graphene surface (dark spots). The high-resolution TEM images NiO-CuO/G composite showed the hexagonal graphitic edges with parallel alignment to the longitudinal axis of graphitic layers, and displayed a typical crumpled structure consisting of several graphene layers (Oh et al. 2011). These observations are in agreement with the result obtained by Lan Li et al (2018), who prepared a graphenecobalt/nickel composite on carbon cloth electrode (Gr-Co/Ni-CC). They found that there are large amounts of small sized Co/Ni composite that were randomly deposited on the surface of the crumpled graphene sheets.

SEM images of the electrocatalysts showed the surface morphologies and its composition as indicated in Figure S3. It could be noticed that the distribution of both synthesized particles ( $\mathrm{NiO}$ and $\mathrm{CuO}$ ) granular pattern on the graphene surface. In addition, there are a large quantity of small particulate (white spots) with randomly aggregation (packed uniformly) on a wrinkled and crumpled structures of graphene (gray area). Presumably, that NiO and CuO are effectively precipitated on graphene by the in-situ preparation method. The EDX results, in addition to elemental mapping images as shown in Fig. 3 , which demonstrate that $\mathrm{C}, \mathrm{O}, \mathrm{Ni}$ and $\mathrm{Cu}$ are components of the synthesized electrocatalysts. The weight and atomic percentages of different elements are presented in supplementary Table S1. We imply that these percentages are close to the nominal ratio of carbon, oxygen, Ni \& $\mathrm{Cu}$. These findings proven that Ni/Cu was successfully deposited on a graphene surface.

\subsection{Electrochemical measurements using a rotating ring-disk}

Figure 4 represents the polarization curves of oxygen reduction on $30 \% \mathrm{Pt} / \mathrm{C}$ and NiO-CuO/G electrodes in $\mathrm{O}_{2}$-saturated PBS at a scan rate of $10 \mathrm{mV} \mathrm{s}{ }^{-1}$ and a rotation speed of $1200 \mathrm{rpm}$. It could be noticed that the onset potentials of $\mathrm{Pt} / \mathrm{C}$ and $\mathrm{NiO}-\mathrm{CuO} / \mathrm{G}$ are significantly in the positive direction. Although the onset potential of $\mathrm{Pt} / \mathrm{C}$ has a more positive onset potential $(400 \mathrm{mV})$ than that obtained in case of NiO-CuO/G (163 mV), the diffusion limiting current density for $\mathrm{NiO}-\mathrm{CuO} / \mathrm{G}\left(4.161 \mathrm{mAcm}^{-2}\right.$ at $\left.-600 \mathrm{mV}\right)$ is comparable to the current density of $\mathrm{Pt} / \mathrm{C}\left(4.781 \mathrm{mAcm}^{-2}\right)$ at the same potential. This result suggests that NiO$\mathrm{CuO} / \mathrm{G}$ considerably enhance the performance of redox reaction and have an electrochemical activity towards ORR comparable to Pt.

In order to explore the diffusion zone of current densities for Pt/C and NiO-CuO/G, LSV were performed at different rotational speeds ranging from 200 to 2400 rpm in $\mathrm{O}_{2}$-saturated PBS at scan rate of $10 \mathrm{mV} \mathrm{s}^{-1}$ as indicated in Fig. 5. It could be observed from Pt/C LSV curves that the reduction current density increased from -3.219 to $-4.971 \mathrm{mAcm}^{-2}$ with increase in rotational speed from 200 to 2400 and decreasing the potential scan to more negative values. It can be explained by the transmission of steady streams of the bulk solution to the electrode surface during high rotation, while the bulk solution that far from the electrode surface remains well stirred by the convection and the shortened of diffusion distance at speeds (Huang et al. 2015; K. Scott 2015). The NiO$\mathrm{CuO} / \mathrm{G}$ electrocatalyst exhibited a similar behavior, in which the reduction current density increased from -2.215 to $-4.869 \mathrm{mAcm}{ }^{-2}$ at a potential range from -0.1 to $-0.4 \mathrm{~V}$. Furthermore, it is shown that there is a flat limiting current plateau (indefinite-expressed plateau), implying that the reduction mechanism for $\mathrm{O}_{2}$ is quick enough and the reaction occurred on the outer porosity surface of the electrode (Zhang et al. 2010). Similar results are reported for oxygen reduction of cobalt oxide $\left(\mathrm{CO}_{3} \mathrm{O}_{4}\right)$ micro-particles directly grown on stainless steel mesh by using an ammonia-evaporation-induced method and evaluated in batch-fed dual-chamber MFC (Gong et al. 2014). This can be explained by the reduced diffusion range at elevated rotations of Pt/C and NiO-CuO/G electrocatalysts due to increasing in the amount of oxygen diffused at the electrode surface as a direct result of increasing the rotation speed in contracts with other studies (Faubert et al. 2018; Huang et al. 2015). 
The data from RDE polarization curves are used to plot the Koutecky-Levich $(\mathrm{K}-\mathrm{L})$ relationship, where inverse current density $\left(j^{-1}\right)$ is directly related to inverse square root of rotation rate $\left(\omega^{-1 / 2}\right)$ at different potential values (i.e., -0.1 to $-0.4 \mathrm{~V}$ vs. SHE) (Figs. $5 \mathrm{c}$ and $5 \mathrm{~d}$ ). It could be observed from $\mathrm{K}-\mathrm{L}$ plots of both electrocatalysts are distinctly parallel and linear, which signify an enhanced electrocatalytic behavior towards ORR (kinetically more facile). The number of electrons $(\mathrm{n})$ transferred associated with ORR is determined from the slope of the Koutecky-Levich $(\mathrm{K}-\mathrm{L})$ plots. It is calculated from to be 3.94 at $-0.1 \mathrm{~V}$ and 4 at $-0.4 \mathrm{~V}$ in case of $\mathrm{Pt} / \mathrm{C}$, while it is about $\sim 4$ at $-0.1 \mathrm{~V}$ and 3.56 at $-0.4 \mathrm{~V}$ for NiO-CuO/G . Thus, the four-electron pathway mainly dominates the ORR in Pt/C similar to ORR catalyzed by NiO-CuO/G according to the following equation:

$\mathrm{O}_{2}+2 \mathrm{H}_{2} \mathrm{O}+4 \mathrm{e}^{-} \rightarrow 4 \mathrm{OH}^{-}$

The results demonstrate an improved electron transfer for the NiO-CuO/G electrode (A. Esfandiari, M. Kazemeini 2016). The distribution of electron transfer numbers confirms that the NiO-CuO/G could be improved towards ORR and thus improving the performance of cathode in MFCs in neutral media. These results are in agreement with previous results, in which silver-tungsten carbide (Ag-WC/C) nanohybrid showed comparable ORR efficiency to Pt/C in MFC (Gong et al. 2013). This high ORR activity could be due to the synergistic effect between carbon, WC and Ag nanoparticles. It can be found that the NiO-CuO/G can contribute an efficient catalytic ORR activity. Therefore, it can be suggested that the catalytic activity towards ORR has emerged from the combined impact of synergetic material between $\mathrm{NiO}$ and the $\mathrm{CuO}$ loaded on graphene. Furthermore, the efficient ORR performance of the NiO-CuO is due to the high catalytic surface area provided by the NiO-CuO particle allowing high deposition of the catalyst on the graphene surface and the high porosity of the composites. These results have a pivotal role in addressing the cheaper Pt-free mixed metal oxides as the electrocatalysts rather than using Pt/C electrocatalyst in the MFC without significantly impeding the performance.

\subsection{Performance of NiO-CuO/G in MFC}

\subsubsection{Electricity generation:}

The previous analysis of electrochemical results showed that the NiO-CuO/G composite is an efficient electrocatalyst for ORR compared to the commercial $\mathrm{Pt} / \mathrm{C}$, suggesting that it can be used as a potential cathode for MFC application. Thus, the biochemical and electrochemical reaction rates as well as long-term stability of the NiO-CuO/G were evaluated under open-circuit voltage condition (OCV) using acetate as the sole electron donor, and compared to a Pt/C-based MFC (Figure S4).In this case, the current is not flown through the external circuit, and therefore the power and current are equal to zero. Improvements in anodic metabolic activity lead to substrate oxidation leading to increase in OCV during the subsequent cycles. After 62 days of operation, MFCs exhibited a stable OCV of $835 \mathrm{mV}$ for Pt/C-based MFC and654 mV for NiO-CuO/G-based MFC. It could be concluded that the maximum OCV values are correlated with an increase in the reaction rate allowing the adsorption of a higher amount of oxygen on the electrocatalyst surface (Pareek et al. 2019). Furthermore, it is found that the NiO-CuO/G is a proficient electrocatalytic cathode substance for the application of MFC as the Pt/C catalyst. The performance of NiO-CuO/G cathode in MFC was compared to Pt/C after an adaptation period. The cell potential for both MFCs was measured across an external resistance of $1000 \Omega$. Figure 6 (Huang et al. 2015) illustrates the power density (PD) and the potential generation (V) curves during three cycles as a function of the current density $(j)$. The maximum voltage output of NiO-CuO/G-based MFC is slightly lower than that of the Pt/C-based MFC (541 mV versus $720 \mathrm{mV}$ ).

$\mathrm{Pt} / \mathrm{C}$ cathode exhibited a maximum power density generation of $50.4 \mathrm{mWm}^{-2}$ at a cell current density of $152 \mathrm{~mA} \mathrm{~m}^{-2}$, which was 2-fold higher than that for $\mathrm{NiO}-\mathrm{CuO} / \mathrm{G}$ cathode $\left(21.3 \mathrm{mWm}^{-2}\right)$ at a cell current density of $113.04 \mathrm{mAm}^{-2}$ as shown in Fig. 7. In addition, the NiO-CuO/G has significantly less activation potential loss in the high current region of the range $\left(0-124 \mathrm{~mA} \mathrm{~m}^{-2}\right)$ than that of $\mathrm{Pt} / \mathrm{C}\left(0-160 \mathrm{~mA} \mathrm{~m}^{-2}\right)$, which signifies the major basis for better catalytic activity of the prepared catalyst due to improvements in oxygen mass transfer (Haoyu et al. 2007). As explained previously, the internal resistance can be obtained from the slope of the voltage plot versus current density as shown in Fig. 7. The internal resistance of NiO-CuO/G (11955 $\Omega$ ) is slightly higher than the Pt/C $(9471 \Omega)$. Our results suggest that NiO-CuO/G cathode could replace Pt/C cathode in MFCs, mainly due to its high catalytic activity towards ORR owing to the synergistic interaction and the improved contact area among the unique graphene as based supporting structure and $\mathrm{NiO} / \mathrm{CuO}$ (Furukawa et al. 2005).

\subsubsection{Organic matter removal:}

In the case of NiO-CuO/G-based MFC, the COD removal percentage ( $92 \pm 1.1 \%$ ) was slightly lower than that obtained from Pt/C MFC ( $93 \pm 0.43 \%)$. Depending on the intensive development of the bacterial cells at high COD removal value forming the biofilm, it can be presumed that the higher COD removal is directly correlated to the enhanced substrate utilization and the comparatively higher performance with improved power output (Papiya et al. 2017; Ghasemi et al. 2013). The high surface area of the graphene's uniform distribution and dispersion of the prepared catalyst led in higher voltage as well as higher current output of the system with higher power output. In a brief conclusion, the overall reaction of prepared NiO-CuO/G with higher removal efficiency ( $92 \pm 1.1 \%$ ) on acetate specifies that it can perform as an effective electrocatalyst over other MFC catalysts studies. Pt/C shows significantly higher Coulombic efficiency ( $\mathrm{C}_{\mathrm{E}}$ ) ( $35 \pm 0.69 \%)$ than $\mathrm{NiO}-\mathrm{CuO} / \mathrm{G}(25 \pm 0.71 \%)$, these results suggest that the $\mathrm{C}_{\mathrm{E}}$ is determined mainly by the cathode variations. These results can be attributed to the ideal properties of NiO-CuO/G electrocatalyst, making the MFC more feasible for scaling up and enhancing the MFC efficiency. In this context, the deposition of $\mathrm{NiO}-\mathrm{CuO}$ on the graphene has an advantage in maximizing the availability of high surface area for mass transfer of reactants and providing better graphene collection and acceptance of electrons. In particular, this can be clarified principally by the reality that the performance of NiO-CuO/G on the cathodes highlights the significant efficiency compared to that of the Pt/C (Yan et al. 2012).

Table 1 summarizes experimental data of using Ni-based electrocatalysts as efficient ORR cathode in MFCs. It is obvious that Ni-based cathodes exhibited high power density in MFCs, which are comparable to Pt-based MFCs; a main cause was most likely due to the high ORR electrocatalytic activity of Ni-based electrocatalysts. 
Table 1

A comparative study of the performance of MFC between using different nickel-based electrocatalyst

\begin{tabular}{|c|c|c|c|c|c|c|c|c|c|c|}
\hline Cathode catalyst & $\begin{array}{l}\text { Anode } \\
\text { material }\end{array}$ & $\begin{array}{l}\text { Cathode } \\
\text { material }\end{array}$ & Substrate & $\begin{array}{l}\text { MFC } \\
\text { configuration }\end{array}$ & microorganism & $\begin{array}{l}\text { Open } \\
\text { Circuit } \\
\text { Potential } \\
(\mathrm{mV})\end{array}$ & $\begin{array}{l}\text { closed } \\
\text { circuit } \\
\text { voltage } \\
\text { (mV) }\end{array}$ & $\begin{array}{l}\mathrm{PD}_{\max } \\
\left(\mathrm{mW} \cdot \mathrm{m}^{-}\right. \\
\left.{ }^{2}\right)\end{array}$ & $\begin{array}{l}\text { Percentage } \\
\text { to Pt } \\
\text { cathode } \\
\text { (\%) }\end{array}$ & Ref. \\
\hline $\mathrm{NiO}-\mathrm{CuO} / \mathrm{G}$ & $\begin{array}{l}\text { Carbon } \\
\text { felt }\end{array}$ & $\begin{array}{l}\text { carbon } \\
\text { cloth }\end{array}$ & $\begin{array}{l}\text { sodium } \\
\text { acetate }\end{array}$ & Air cathode & $\begin{array}{l}\text { Activated } \\
\text { sludge }\end{array}$ & 654 & 541 & 21.25 & 42.16 & This study \\
\hline $\begin{array}{l}\text { Nickel } \\
\text { nanoparticles on } \\
\text { reduced graphene } \\
\text { oxide }\end{array}$ & $\begin{array}{l}\text { graphite } \\
\text { brush }\end{array}$ & $\begin{array}{l}\text { carbon } \\
\text { cloth }\end{array}$ & $\begin{array}{l}\text { sodium } \\
\text { acetate }\end{array}$ & Air cathode & $\begin{array}{l}\text { Anaerobic } \\
\text { digester sludge }\end{array}$ & 602 & 136.8 & 581 & 26.4 & $\begin{array}{l}\text { (Valipour ‘ } \\
\text { al. 2016) }\end{array}$ \\
\hline $\begin{array}{l}\text { naphthalocyanine } \\
\text { on carbon black } \\
\text { (NPc/C) }\end{array}$ & $\begin{array}{l}\text { carbon } \\
\text { paper }\end{array}$ & $\begin{array}{l}\text { carbon } \\
\text { paper }\end{array}$ & Wastewater & $\begin{array}{l}\text { Double } \\
\text { chamber }\end{array}$ & $\begin{array}{l}\text { Anaerobic } \\
\text { digester sludge }\end{array}$ & 602 & 168 & 29.7 & 36.53 & $\begin{array}{l}\text { (Rae et al. } \\
\text { 2011) }\end{array}$ \\
\hline $\begin{array}{l}\text { Nickel oxide and } \\
\text { carbon nanotube } \\
\text { composite } \\
\text { (NiO/CNT) }\end{array}$ & $\begin{array}{l}\text { carbon } \\
\text { felts }\end{array}$ & $\begin{array}{l}\text { Carbon } \\
\text { cloth }\end{array}$ & glucose & Air cathode & $\begin{array}{l}\text { acclimated } \\
\text { sludge from } \\
\text { methane- } \\
\text { generating } \\
\text { pond }\end{array}$ & 772 & 380 & 670 & $N / A^{*}$ & $\begin{array}{l}\text { (Huang et } \\
2015 \text { ) }\end{array}$ \\
\hline $\begin{array}{l}\text { Pt-Ni Alloy } \\
\text { Nano particles on } \\
\text { Carboxyl Multi- } \\
\text { Wall Carbon } \\
\text { Nanotubes (Pt- } \\
\text { Ni/MWNT) }\end{array}$ & $\begin{array}{l}\text { Carbon } \\
\text { cloth }\end{array}$ & $\begin{array}{l}\text { carbon } \\
\text { cloth }\end{array}$ & glucose & Air cathode & $\begin{array}{l}\text { pre- } \\
\text { domesticated } \\
\text { bacteria from } \\
\text { another double } \\
\text { chamber MFC }\end{array}$ & 740 & 570 & 1.22 & 86.8 & $\begin{array}{l}\text { (Yan et al. } \\
\text { 2012) }\end{array}$ \\
\hline $\begin{array}{l}\text { Ni-Tetra } \\
\text { Sulfonated } \\
\text { phthalocyanine }\end{array}$ & $\begin{array}{l}\text { Stainless } \\
\text { steel } \\
\text { foam } \\
\text { was } \\
\text { modified } \\
\text { with rGO }\end{array}$ & $\begin{array}{l}\text { Carbon } \\
\text { felt }\end{array}$ & $\begin{array}{l}\text { sodium } \\
\text { acetate }\end{array}$ & $\begin{array}{l}\text { Double } \\
\text { chamber }\end{array}$ & $\begin{array}{l}\text { a mixture of } \\
\text { compost } \\
\text { garden's } \\
\text { leachate }\end{array}$ & & & 24.8 & $N / A^{*}$ & $\begin{array}{l}\text { (Champav } \\
\text { et al. } 2015\end{array}$ \\
\hline $\begin{array}{l}\text { Graphene/nickel } \\
\text { hybrids }\end{array}$ & $\begin{array}{l}\text { Graphite } \\
\text { plate }\end{array}$ & $\begin{array}{l}\text { Graphite } \\
\text { plate }\end{array}$ & $\begin{array}{l}\text { Waste } \\
\text { water }\end{array}$ & $\begin{array}{l}\text { Dual } \\
\text { chamber }\end{array}$ & Wastewater & & & 34 & $\mathrm{~N} / \mathrm{A}^{*}$ & $\begin{array}{l}\text { (Kartick et } \\
\text { al. 2016) }\end{array}$ \\
\hline $\begin{array}{l}\text { Nickel } \\
\text { nanoparticles }\end{array}$ & $\begin{array}{l}\text { carbon } \\
\text { paper }\end{array}$ & $\begin{array}{l}\text { carbon } \\
\text { paper }\end{array}$ & glucose & $\begin{array}{l}\text { Dual } \\
\text { chamber }\end{array}$ & $\begin{array}{l}\text { Palm oil mill } \\
\text { effluent } \\
\text { anaerobic } \\
\text { sludge }\end{array}$ & 751.8 & & 94.4 & 78.15 & $\begin{array}{l}\text { (Ghasemi } \\
\text { al. 2013) }\end{array}$ \\
\hline
\end{tabular}

\section{CNT: carbon nanotube, MWNT: multi-wall carbon nanotubes, * : not available}

There are also distinct differences in the literature between the reported values for Pt/C. The performance of our synthesized electrocatalyst are comparable to results that conducted by Champavert et al who fabricated a carbon felt modified with poly $\mathrm{Ni}$ (II) tetra sulfophthalocyanine as the cathode using acetate as organic source (Champavert et al. 2015). In another study, Valipour et. al they evaluated the feasibility of nickel/reduced graphene (Ni/RGO) nano particle composite as novel cathode catalysts in single chamber air-cathode MFCs (Valipour et al. 2016). The Ni/RGO showed better power performance (581 mWm ${ }^{-}$ ${ }^{2}$ ) than this study. This difference in P.D may be due to many factors including the operational condition, the MFCs design, the type \& surface area of the anode, the difference in the bacterial community, and the different of supporting material of the electrocatalyst and its projected surface area. These previous studies reported that non-precious nickel electrocatalysts generally have goodcatalytic activity and stability, which are comparable to Pt and can be used as a cathode catalyst in the MFC

\subsubsection{Visualization of electroactive anodic biofilm:}

The surface morphologies of fixed, intact anodic biofilm carbon felt electrode as well as and the bare carbon felt anode were investigated by SEM. As depicted in supplementary Figure S5, the SEM micrographs revealed that the surface morphology of bare carbon felt was very smooth with numerous straight carbon fibers crossed over each other layer by layer, forming a mesh-like structure with a diameter of nearly $20 \mu \mathrm{m}$ and the edges are observed in the axial and cylindrical shape. While the formed anodic biofilm covered the surface and internal pores of carbon felt anode. Furthermore, the electron micrographs revealed appearance of bacteria as rod-shaped individual cells. They were approximately $1.3 \mu \mathrm{m}$ long. We can observe that all the cells were in actual physical contact with the electrode. Similarly, Yang et.al. (2012) showed that anodic biofilm of an MFC fed with acetate had rod-shape bacterial cells with $0.2-0.3$ mm wide and 1.5-2.5 mm long (Yang et al. 2012).

TEM provided important details on the internal structure of the anodic biofilm, microbial physiologyand the relationship between microbes and minerals. TEM images in Fig. 8 indicates four isolates (1C-4C) ultrastructure rod-shaped surface. Major cellular ultrastructural properties in lipid membrane and cytoplasm have often been observed. We also found that the cytoplasmic lipid inclusions of isolates accumulated mild (1C and $4 \mathrm{C})$ to severe (2C and $3 \mathrm{C}$ ). Isolates of this bacterial layer had an apparent thickness of about $1 \mu \mathrm{m}$ on the lateral dimension. Based on this morphological study, it can be concluded that the effective formation of electroactive biofilm which partially responsible for the MFC activity with an efficient cathode. 


\subsubsection{Biochemical identification of isolated anodic communities by vitek2 compact system method:}

The MFC anode communities enriched with acetate were identified biochemically using the Vitek2 compact system method. The analysis revealed that there are four distinct dominant bacterial classes exist and three of these are gram negative (-ve) (Table 2), which are commonly found in the anode of MFCs, such as Gammaproteobacteria (S. Ishii, S. Suzuki, T.M. Norden-Krichmar, T. Phan, G.Wanger, K.H. Nealson \& Y.A. Gorby 2014) and Firmicutes (K.C. Wrighton, P. Agbo, F. Warnecke, K.A. Weber, E.L. Brodie, T.Z. DeSantis \& Hugenholtz, G.L. Andersen 2008). Interestingly, the fact that Gammaproteo bacteria in bioelectrochemical systems display a high current and power output is observed as an electrochemically active microbe (Daniel Aguirre de carcer, Phuc Thi Ha 2011; Xin et al.

2020). Firmicutes have been found to transmit the electrons directly to the anode surface as Bacillus cereus, Bacillus Thuringiensis/mycoides. It considers the fundamental property of living organisms to absorb some of the respiratory energy in the form of electrons and to use as an alternative for respiration directly in the absence of an electron acceptorthe electron flow can then continue, and the organism can begin to metabolize. On the basis of this simplistic analysis, the anode itself was supposed to be a pathway through anaerobic enrichment isolates electrical consortia. 
Table 2

Biochemical analysis details of anodic biofilm

\begin{tabular}{|c|c|c|c|c|c|}
\hline Characteristic & isolates & & Characteristic & isolates & \\
\hline & 2 & 3 & & 1 & 4 \\
\hline APPA & - & + & APPA & + & + \\
\hline $\mathrm{H} 2 \mathrm{~S}$ & - & + & PyrA & + & + \\
\hline BGLU & - & - & dMAN & - & - \\
\hline ProA & - & + & PLE & - & - \\
\hline SAC & + & + & dGLU & + & + \\
\hline ILATK & + & + & ELLM & - & - \\
\hline GlyA & - & - & BXYL & - & - \\
\hline 0129R & + & - & AGAL & - & - \\
\hline ADO & - & - & BGAL & - & - \\
\hline BNAG & - & + & BMAN & - & - \\
\hline dMAL & + & + & INU & + & + \\
\hline LIP & + & - & OLD & - & - \\
\hline dTAG & + & - & LysA & - & - \\
\hline AGLU & - & - & CDEX & - & - \\
\hline ODC & + & + & $\operatorname{MdX}$ & - & - \\
\hline GGAA & - & + & $\mathrm{dMLZ}$ & - & - \\
\hline PyrA & - & + & $\mathrm{PHC}$ & - & - \\
\hline AGL Tp & - & + & ESC & + & + \\
\hline dMAN & + & - & AspA & - & - \\
\hline PLE & - & - & $\mathrm{dGAL}$ & - & - \\
\hline dTRE & + & - & AMAN & - & - \\
\hline SUCT & + & + & NAG & + & + \\
\hline LDC & + & - & PVATE & + & + \\
\hline IML Ta & - & - & $\mathrm{dRIB}$ & + & + \\
\hline IARL & - & - & TTZ & $(-)$ & $(-)$ \\
\hline dGLU & + & - & LeuA & + & + \\
\hline dMNE & + & - & AlaA & $(+)$ & $(+)$ \\
\hline TyrA & + & + & GLYG & - & - \\
\hline CIT & - & - & MTE & + & + \\
\hline NAGA & - & - & AGLU & $(-)$ & $(-)$ \\
\hline IHISa & - & - & $\mathrm{PSCNa}$ & - & - \\
\hline ELLM & - & + & POLYB_R & + & + \\
\hline dCEL & - & - & PheA & + & + \\
\hline GGT & - & + & TyrA & - & - \\
\hline BXYL & - & - & INO & - & - \\
\hline URE & - & - & GlyA & - & - \\
\hline MNT & - & - & IRHA & - & - \\
\hline AGAL & $(-)$ & - & dTAG & - & - \\
\hline CMT & + & - & $\mathrm{NaCl} 6.5 \%$ & + & + \\
\hline
\end{tabular}




\begin{tabular}{|c|c|c|c|c|c|}
\hline Characteristic & isolates & & Characteristic & isolates & \\
\hline ILATa & - & - & ProA & - & - \\
\hline BGAL & + & - & BNAG & + & + \\
\hline OFF & + & - & MdG & - & - \\
\hline BALap & - & - & dMAN & - & - \\
\hline dSOR & + & - & BGLU & - & - \\
\hline $5 K G$ & - & - & dTRE & + & + \\
\hline PHOS & - & + & KAN & + & + \\
\hline BGUR & - & - & dMNE & - & - \\
\hline Probable identity & Escherichia coli & Shewanella putrefaciens & & Bacillus cereus & Bacillus Thuringiensis/mycoides \\
\hline
\end{tabular}

\section{Conclusion}

This research provides new perspectives into discovering effective non-precious mixed metal oxides (NiO-CuO/G) cathode electrocatalyst as a replacement for noble and very costly Pt/C for practical applications of MFCs. The successful preparation of NiO-CuO/G electrocatalyst was confirmed by XRD, TEM, SEM and EDX analysis, and its electrochemical characterization showed high selectivity and electrocatalytic activity towards the ORR that follow the four-electron pathway using LSV measurements. The efficiency of $\mathrm{NiO}-\mathrm{CuO} / \mathrm{G}$ with a maximum PD $\left(21.3 \mathrm{mWm}^{-2}, \mathrm{C}_{\mathrm{E}}=25 \pm 0.71 \%\right)$ is comparable to Pt/C (50.4 mWm ${ }^{-2}, \mathrm{C}_{\mathrm{E}}$ $=35 \pm 0.69 \mathrm{in} \mathrm{MFCs}$. The enhanced electrocatalytic activity of NiO-CuO/G may be mainly due to its high surface area and synergistic effect between NiO/CuO and graphene. These synergistic effects provide $\mathrm{NiO} / \mathrm{CuO}$ surface with large amounts of active sites confirming the stability of the electrocatalyst and the electrical conductivity and subsequence enhanced the performance of MFCs. Both SEM and TEM analysis of anodic biofilm showed the rod shaped structure of electroactive microorganisms, confirming that the generated electricity are due to the formed electroactive biofilm on the surface of the anodic electrode. In addition, the biochemical characterization of the anodic communities reveals a possible pathway for the isolation of electrochemically active bacteria via anaerobic enrichment and is primarily anticipated as a tool for selecting EAB consortia.

\section{Declarations}

Ethical approval: This article does not contain any studies with human participants or animals performed by any of the authors.

Consent to Participate: Not applicable.

Consent to Publish: Not applicable.

\section{Author contribution statement}

Dena Z Khater, Rabab S Amin and Kaml M El-Khatib conceived, performed and designed the research. Mohamed Mahmoud, Monera O Zhran , Zeinab K Abd El-Aziz and Dena Z Khater analyzed data . Helmy M Hassan, Monera O Zhran and Zeinab K. Abd El-Aziz contributed analytical tools for isolation and identification of microbial community. Dena Z. Khater wrote the first draft of the manuscript. All authors read and approved the final manuscript.

Funding: This research was financially supported by the National research Centre, Egypt.

Competing interests: The authors declare that they have has no conflict of interest.

Availability of data and materials: All data generated or analysed during this study are included in this published article and its supplementary information files

\section{Acknowledgements}

This study was financially supported by the National research Centre, Egypt. We also are grateful to the Pilot Plant Department staff of the Chemical Engineering Division at the National research Centre for their help throughout this study.

\section{References}

A. Esfandiari, M. Kazemeini, D.B., 2016. Synthesis, characterization and performance determination of an Ag@Pt/C electrocatalyst for the ORR in a PEM fuel cell. Int. J. Hydrogen Energy, 41, pp.20720-20730.

Andrew, D.E., Clescenri, L.S. \& Breenberg, A.E., 1995. Standard Method for the Examination of Water and Wastewater, 19th ed.. APHA, AWW, WEF, Washington, $D C$, USA, $p p$., 
Anon, Iron- and nitrogen-functionalized graphene as a non-precious metal catalyst for enhanced oxygen reduction in an air-cathode microbial fuel cell. BioMe'rieux., 2006. Vitek2 product information, document 510769-4EN1. bioMe'rieux,. Inc., Durham, NC.

Champavert, J. et al., 2015. Microbial Fuel Cell based on Ni- Tetra Sulfonated phthalocyanine cathode and graphene modified bioanode. Journal of Electroanalytical Chemistry. Available at: http://dx.doi.org/10.1016/j.jelechem.2015.09.012.

Daniel Aguirre de carcer, Phuc Thi Ha, J.K.\& In S.C., 2011. Microbial community differences between propionate- fed microbial fuel cell systems under open and closed circuit conditions. AApplied Microbiology and biotechnology, 89, pp.605-612.

E.Logan, L.H.\& B., 2008. Electricity generation and treatment of paper recycling wastewater using a microbial fuell cell. App/ Microbiol Biotechnol, 80, pp.349355 .

Faubert, P. et al., 2018. A non-noble $\mathrm{Cr}$ - Ni-based catalyst for the oxygen reduction reaction in alkaline polymer electrolyte fuel cells. MRS Communications, 8 , pp.160-167.

Feng, Y. et al., 2008. Brewery wastewater treatment using air-cathode microbial fuel cells. Appl. Microbiol. Biotechnol., 78(5), p.873-880.

Furukawa, K. et al., 2005. Intelligent structure design of membrane cathode assembly for direct methanol fuel cell. Int. J. Energy Res, 29(12), pp.1073-1082.

Ghasemi, M. et al., 2013. Copper-phthalocyanine and nickel nanoparticles as novel cathode catalysts in microbial fuel cells. International Journal of Hydrogen Energy, pp.1-8. Available at: http://dx.doi.org/10.1016/j.ijhydene.2013.01.177.

Gong, X. et al., 2014. A novel stainless steel mesh / cobalt oxide hybrid electrode for efficient catalysis of oxygen reduction in a microbial fuel cell. Biosensors and Bioelectronic, 55, pp.237-241.

Gong, X. et al., 2013. Silver- tungsten carbide nanohybrid for efficient electrocatalysis of oxygen reduction reaction in microbial fuel cell. Journal of Power Sources, 225, pp.330-337. Available at: http://dx.doi.org/10.1016/j.jpowsour.2012.10.047.

H. A. Gasteiger, S. S. Kocha, B.S. and F.T.W., 2005. Activity Benchmarks and Requirements for Pt, Pt-Alloy, and Non-Pt Oxygen Reduction Catalysts for PEMFCs. Applied Catalysis B: Environmental, 56, pp.9-35.

Haoyu, E. et al., 2007. Microbial fuel cell performance with non-Pt cathode catalysts. Journal of Power Sources, 171, pp.275-281.

He, Y., Chen, W., Li, X., Zhang, Z., Fu, J., Zhao, C., and Xie, E., 2013. Free standing three-dimensional graphene/MnO2 composite networks as ultralight and flexible supercapacitor electrodes. ACS Nano, 7, p.174.

Herna'ndez-Ferna'ndez, F.J., Pe'rez de los Ríos, A., S.-G., M.J., Ortiz-Martı́nez, V.M., Lozano-Blanco, L.J., G. \& C., Toma's-Alonso, F., and Quesada-Medina, J., 2015. Recent progress and perspectives in microbial fuel cells for bioenergy generation and wastewater treatment. Fuel Process. Technol., 138, p.284.

Hu H, Fan Y, L.H., 2010. Optimization of NiMo catalyst for hydrogen production in microbial electrolysis cells. Int $J$ Hydrogen Energy.

Huang, J. et al., 2015. Nickel oxide and carbon nanotube composite ( NiO / CNT ) as a novel cathode non-precious metal catalyst in microbial fuel cells. Biosensors and Bioelectronic, 72, pp.332-339. Available at: http://dx.doi.org/10.1016/j.bios.2015.05.035.

Jahan, M., Liu, Z. \& Loh, K.P., 2013. FULL PAPER A Graphene Oxide and Copper-Centered Metal Organic Framework Composite as a Tri-Functional Catalyst for HER , . , pp.5363-5372.

Jiang L-C, Z.W.-D., 2010. A highly sensitive nonenzymatic glucose sensor based on CuO nanoparticles-modified carbon nanotube electrode. Biosens Bioelectron, 25(6), pp.1402-1407.

K. Scott, 2015. Electrochemical principles and characterization of bioelectrochemical system. In microbial electrochemical and fuel cell. pp. $29-66$.

K.C. Wrighton, P. Agbo, F. Warnecke, K.A. Weber, E.L. Brodie, T.Z. DeSantis, P. \& Hugenholtz, G.L. Andersen, J.D.C., 2008. A novel ecological role of the Firmicutes identified in thermophilic microbial fuel cells. ISME J, 2(11), pp.1146-1156.

Kartick, B., Srivastava, S.K. \& Chandra, A., 2016. Graphene / Nickel Nanofiber Hybrids for Catalytic and Microbial Fuel Cell Applications. Journal of Nanoscience and Nanotechnology, 16(1), pp.303-311.

Khater, D.Z., El-Khatib, K.M. \& Hassan, H.M., 2017. Microbial diversity structure in acetate single chamber microbial fuel cell for electricity generation. Journal of Genetic Engineering and Biotechnology, 15(1).

Lee, K. et al., 2009. Oxygen reduction reaction (ORR) catalyzed by carbon-supported cobalt polypyrrole (Co-PPy/C) electrocatalysts. Electrochim. Acta, 54(20), p.4704-4711.

Lefebvre, O. et al., 2012. Effect of increasing anodic NaCl concentration on microbial fuel cell performance. Bioresource Technology, 112, pp.336-340.

Li, L. et al., 2016. CeO2 doped Pt/C as an efficient cathode catalyst for an air-cathode single-chamber microbial fuel cell. RSC Adv., 6, p.25877. 
Lima, F.H.B., Castro, J.F.R. De \& Ticianelli, E.A., 2006. Silver-cobalt bimetallic particles for oxygen reduction in alkaline media. Journal of Power Sources, 161, pp.806-812.

Manuel MF, Neburchilov V, Wang H, Guiot SR, T.B., 2010. Hydrogen production in a microbial electrolysis cell with nickel-based gas diffusion cathodes. $J$ Power Sources, 195, p.5514.

Maruthupandy, M. et al., 2015. Electrical conductivity measurements of bacterial Electrical conductivity measurements of bacterial nanowires from Pseudomonas aeruginosa. Advances in Natural Sciences: Nanoscience and Nanotechnology, 6, pp.045007-045013.

Oh, H. et al., 2011. The influence of the structural properties of carbon on the oxygen reduction reaction of nitrogen modified carbon based catalysts. International Journal of Hydrogen Energy, 36(14), pp.8181-8186.

Papiya, F. et al., 2017. Co / Al 203 -rGO nanocomposite as cathode electrocatalyst for superior oxygen reduction in microbial fuel cell applications: The effect of nanocomposite composition. Electrochimica Acta, 254, pp.1-13. Available at: https://doi.org/10.1016/j.electacta.2017.09.108.

Pareek, A., Sravan, J.S. \& Mohan, S.V., 2019. Exploring chemically reduced graphene oxide electrode for power generation in microbial fuel cell. Materials Science for Energy Technologies, 2, pp.600-606. Available at: https://doi.org/10.1016/j.mset.2019.06.006.

Picoreanu, C. et al., 2007. Computational model for biofim-based microbial fuel cells. Water Res, 41, pp.2921-2940.

R. Burkitt, T. Whiffen, E.H.Y., 2016. Iron phthalocyanine and MnOx composite catalysts for microbial fuel cell applications. Appl. Catal. B: Environ., 181, pp.279-288.

Rae, J. et al., 2011. Application of Co-naphthalocyanine ( CoNPc) as alternative cathode catalyst and support structure for microbial fuel cells. Bioresource Technology, 102(1), pp.342-347. Available at: http://dx.doi.org/10.1016/j.biortech.2010.07.005.

Rojas-carbonell, S. et al., 2017. Transition metal-nitrogen-carbon catalysts for oxygen reduction reaction in neutral electrolyte. Electrochemistry Communications, 75, pp.38-42. Available at: http://dx.doi.org/10.1016/j.elecom.2016.12.011.

Rozendal, R.A. et al., 2008. Towards practical implementation of bioelectrochemical wastewater treatment. Trends Biotechnol, 26(8), p.450-459.

S. Ishii, S. Suzuki, T.M. Norden-Krichmar, T. Phan, G.Wanger, K.H. Nealson, Y.S. \& Y.A. Gorby, O.B., 2014. Microbial population and functional dynamics associated with surface potential and carbon metabolism. ISME J, 8(5), pp.963-978.

Savy M, Coowar F, Riga J, Verbits JJ, Bronoe" I G, B.S., 1990. Investigation of 02 reduction in alkaline media on macrocyclic chelates impregnated on different supports: influence of the heat treatment on stability and activity. J App/ Electrochem, 20(2), pp.260-268.

Shaari, N., and Kamarudin, S.K., 2017. Graphene in electrocatalyst and proton conductiong membrane in fuel cell applications: An overview. Renew. Sust. Energ. Rev., 69, p.862.

Sun, H., 2012. Electricity generation from seafood wastewater in a single- and dual-chamber microbial fuel cell with CoTMPP oxygen-reduction electrocatalyst. J.Chem Technol Biotecnol, (113).

Valipour, A., Ayyaru, S. \& Ahn, Y., 2016. Application of graphene-based nanomaterials as novel cathode catalysts for improving power generation in single chamber microbial fuel cells. Journal of Power Sources, 327, pp.548-556.

Vogl, A., Bischof, F., and Wichern, M., 2016. Increase life time and performance of Microbial Fuel Cells by limiting excess oxygen to the cathodes. Biochem. Eng. J., 106, p.139.

Wang, H., and Ren, Z.J., 2013. A comprehensive review of microbial electrochemical systems as a platform technology. Biotechnol. Adv, 31 , p.1796.

Wang, Z. et al., 2014. Abiotic Oxygen Reduction Reaction Catalysts Used in Microbial Fuel Cells. Chem.Electro.Chem, pp.1813-1821.

Watson, V.J. \& Logan, B.E., 2011. Analysis of polarization methods for elimination of power overshoot in microbial fuel cells. Electrochemistry Communications, 13(1), pp.54-56.

Xin, S. et al., 2020. Electricity generation and microbial community of single-chamber microbial fuel cells in response to Cu 20 nanoparticles / reduced graphene oxide as cathode catalyst. Chemical Engineering Journal, 380(June 2019), p.122446. Available at: https://doi.org/10.1016/j.cej.2019.122446.

Yan, Z. et al., 2012. Carboxyl Multi-Wall Carbon Nanotubes Supported Pt-Ni Alloy Nanoparticles as Cathode Catalyst for Microbial Fuel Cells. Int. J. Electrochem. Sci, 7, pp.10825-10834.

Yan, Z. et al., 2013. Graphene Supported Pt-Co Alloy Nanoparticles as Cathode Catalyst for Microbial Fuel Cells. Int. J. Electrochem. Sci, 8, pp.149-158.

Yang, G. et al., 2016. Preparation of Pt - Ru / C as an Oxygen-Reduction Electrocatalyst in Microbial Fuel Cells for Wastewater Treatment. Catalysts, 150(6), pp.1-10.

Yang, S., Du, F. \& Liu, H., 2012. Characterization of mixed-culture biofilms established in microbial fuel cells. Biomass Bioenergy, 46, p.531-537. 
Youngho, A., 2013. Implementation of microbial fuel cells (MFCs ) -based wastewater treatment. Advanced Materials Research, 684, pp.230-233.

Zeng, L. et al., 2010. Molybdenum carbide as anodic catalyst for microbial fuel cell based on Klebsiella pneumoniae. Biosensors and Bioelectronics, 25(12), pp.2696-2700.

Zhang, H. et al., 2010. 3D non-precious metal-based electrocatalysts for the oxygen reduction reaction in acid media. International Journal of Hydrogen Energy, 35(15), pp.8295-8302.

Zhang, P., Li, K. \& Liu, X., 2014. Carnation-like MnO 2 modi fi ed activated carbon air cathode improve power generation in microbial fuel cells. Journal of Power Sources, 264, pp.248-253. Available at: http://dx.doi.org/10.1016/j.jpowsour.2014.04.098.

\section{Figures}

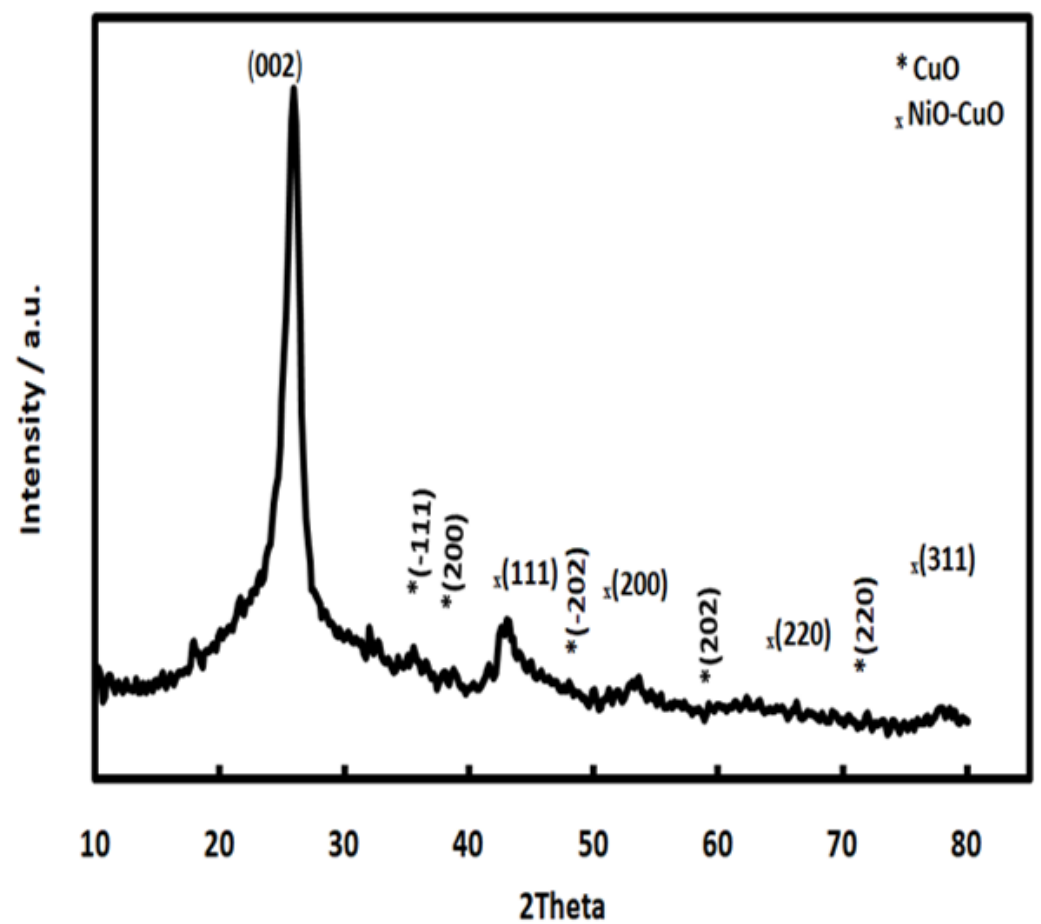

Figure 1

XRD pattern of NiO-CuO/G electrocatalyst. 
a)

b)

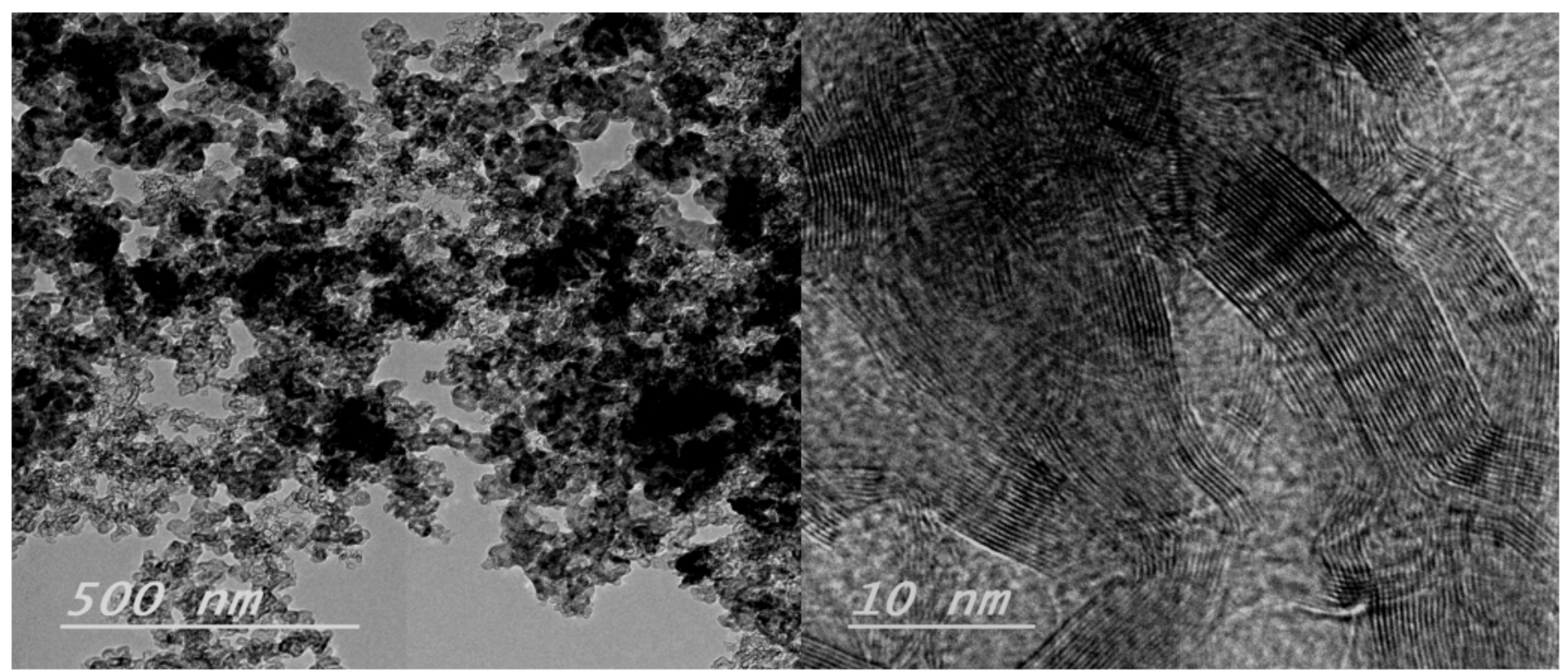

Figure 2

(a) TEM image of the NiO-CuO/G electrocatalyst at $500 \mathrm{~nm}$, (b) detailed view of the electrocatalyst at $10 \mathrm{~nm}$.
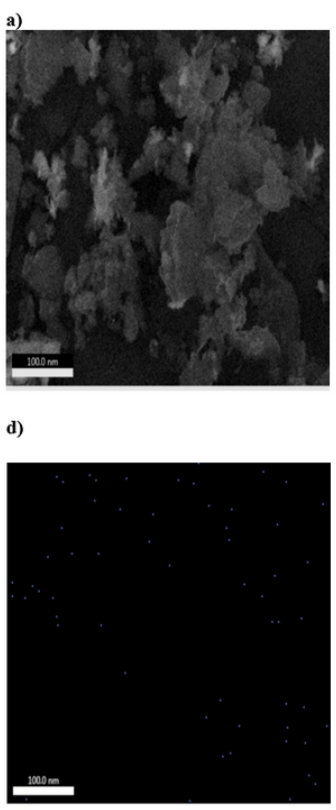

OK ROI (1)

g) Sum Spectrum
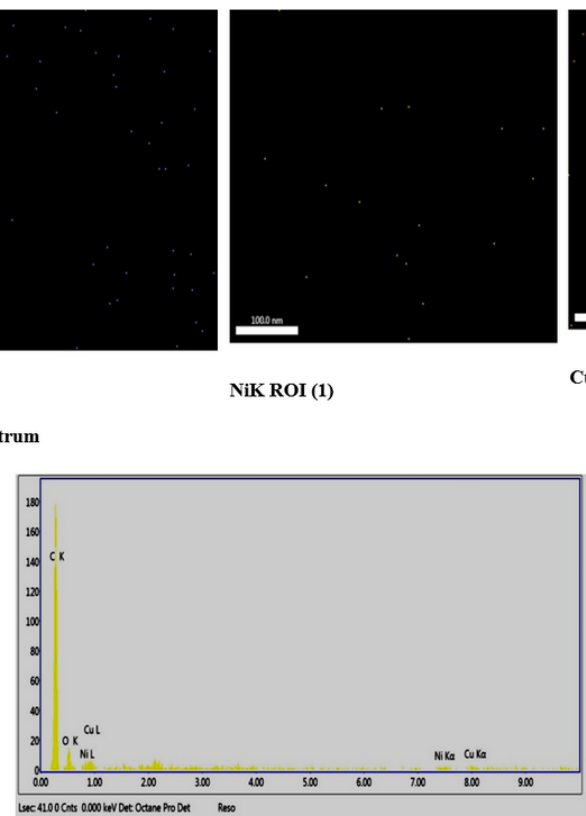

NiK ROI (1)

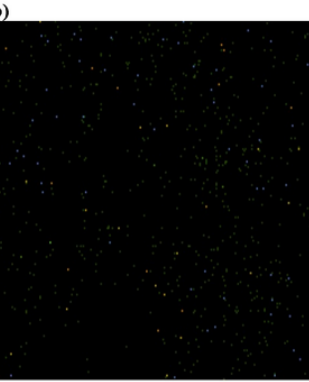

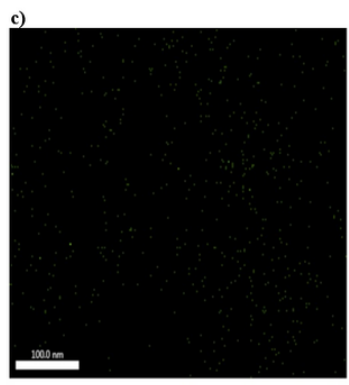

CK ROI (3)

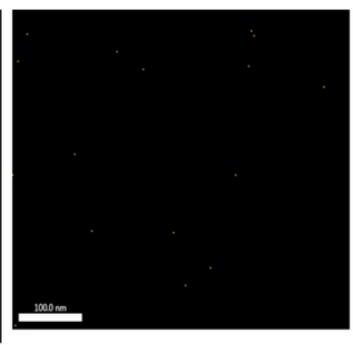

CuK ROI (1) 
Energy dispersive X-ray (EDX) mapping analysis of the NiO-CuO/G electrocatalyst material and the mapping distribution of carbon (c), oxygen (d),nickel (e), and copper atoms (f) (a-f); the EDX spectrum of the NiO-CuO/G electrocatalyst (g).

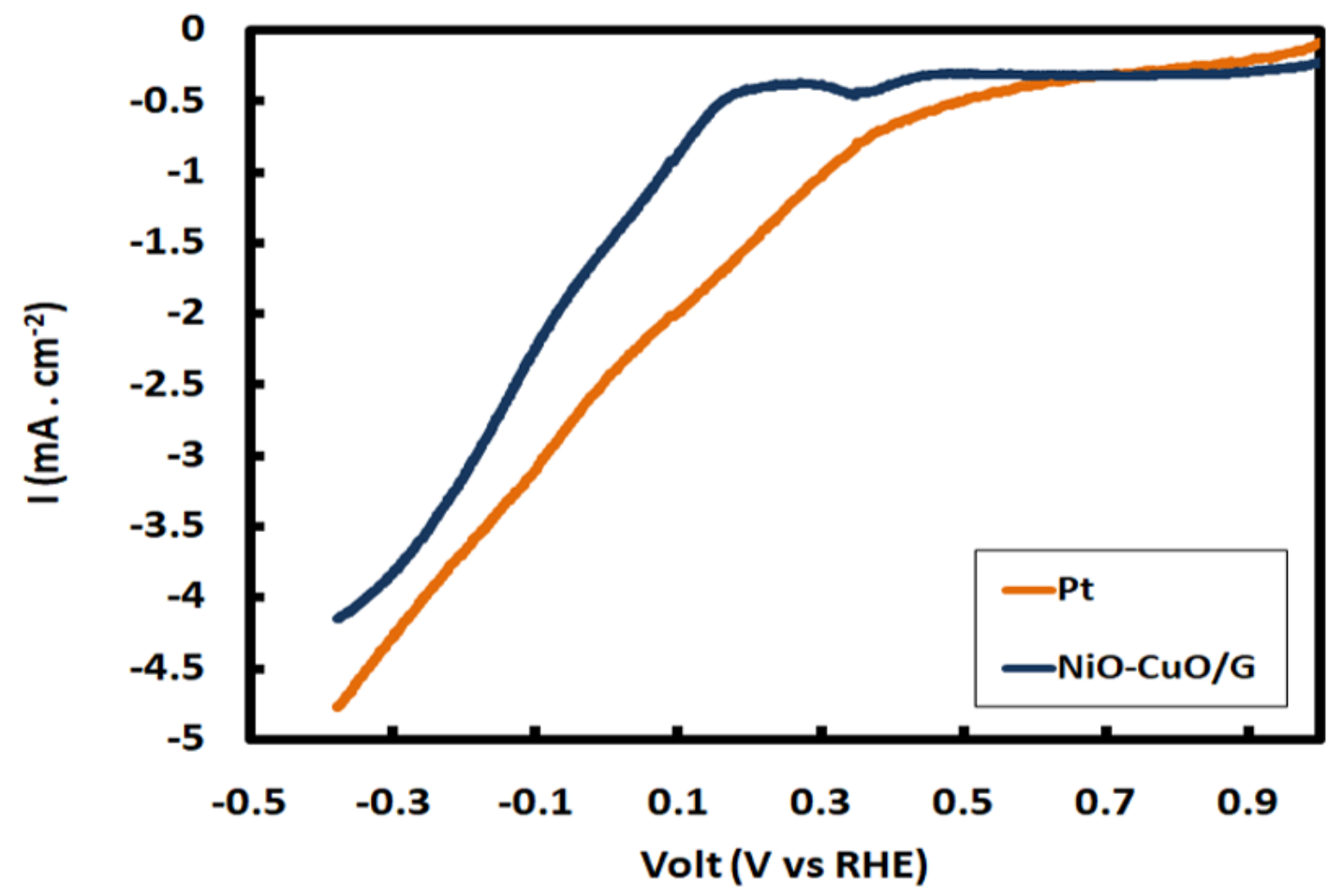

Figure 4

Comparison of the polarization curves for both $\mathrm{Pt} / \mathrm{C}$ and NiO-CuO/G in 02-saturated 50m M PBS at 250C, sweep rate $10 \mathrm{mV}$ s-1, rotation rate: $1200 \mathrm{rpm}$. 


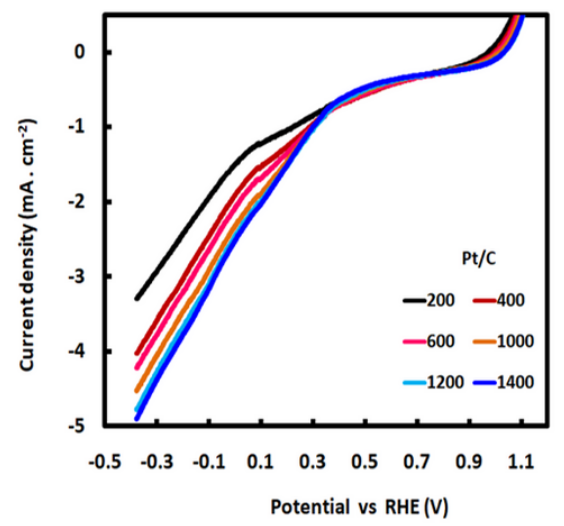

c)

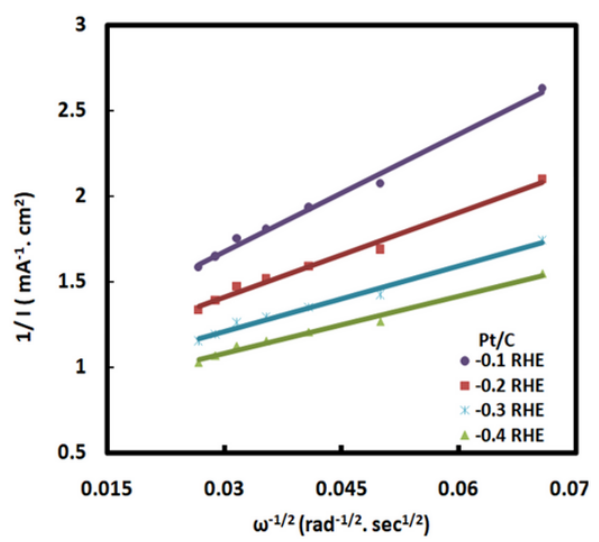

b)

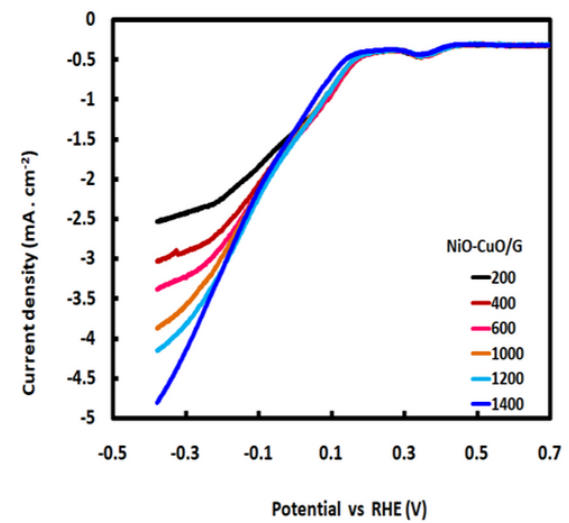

d)

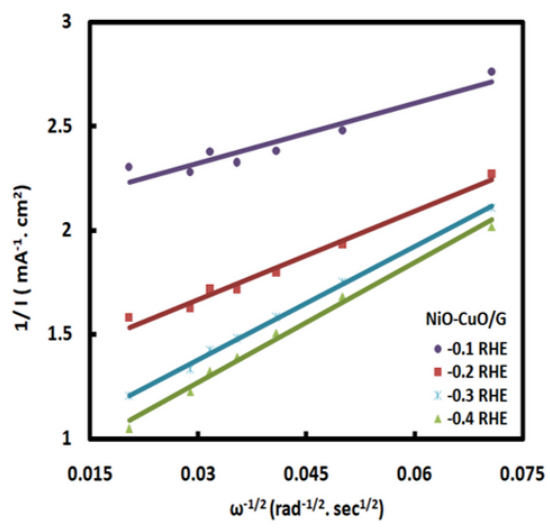

\section{Figure 5}

Current vs. Potential curves obtained from RDE measurements of oxygen reduction reaction on a) Pt/C and b) NiO-CuO/G recorded in neutral PBs solution (50 $\mathrm{mM}$ ) at various rotation velocities with scan rate of $10 \mathrm{mV} \mathrm{s}-1$. Koutecky-Levich (K-L) plots of c) Pt/C and d) NiO-CuO/G at different cathodic potentials from -0.1:-0.4 V. 
a)

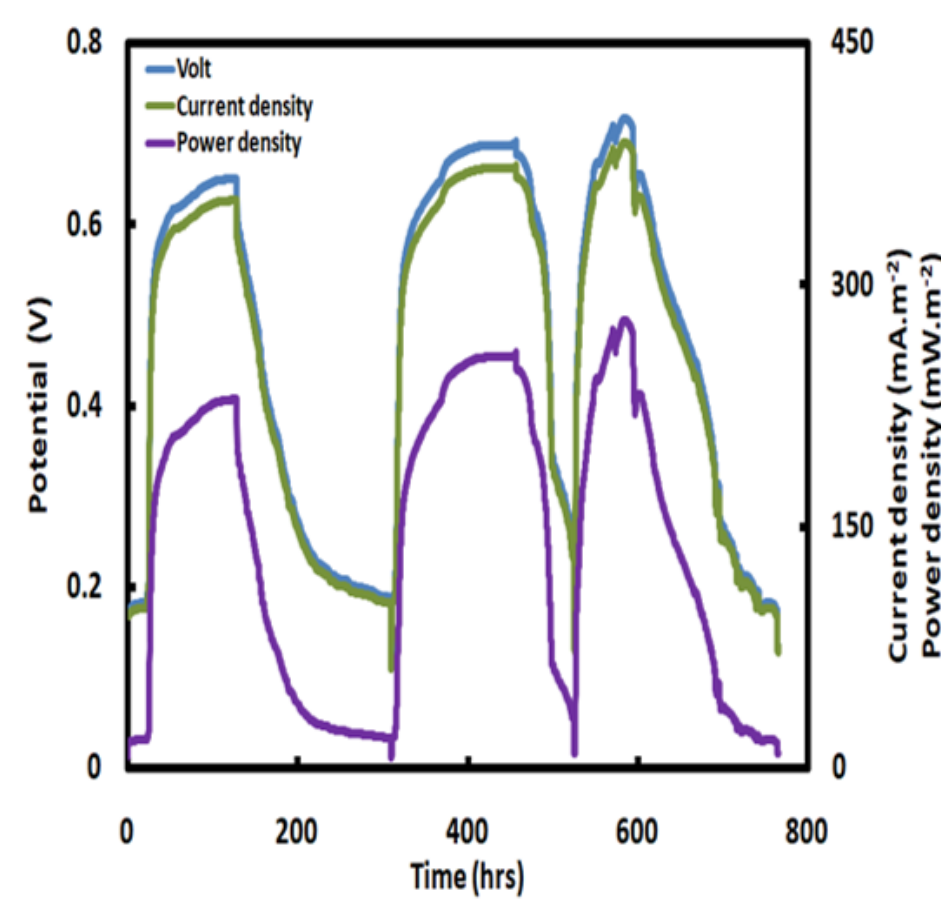

b)

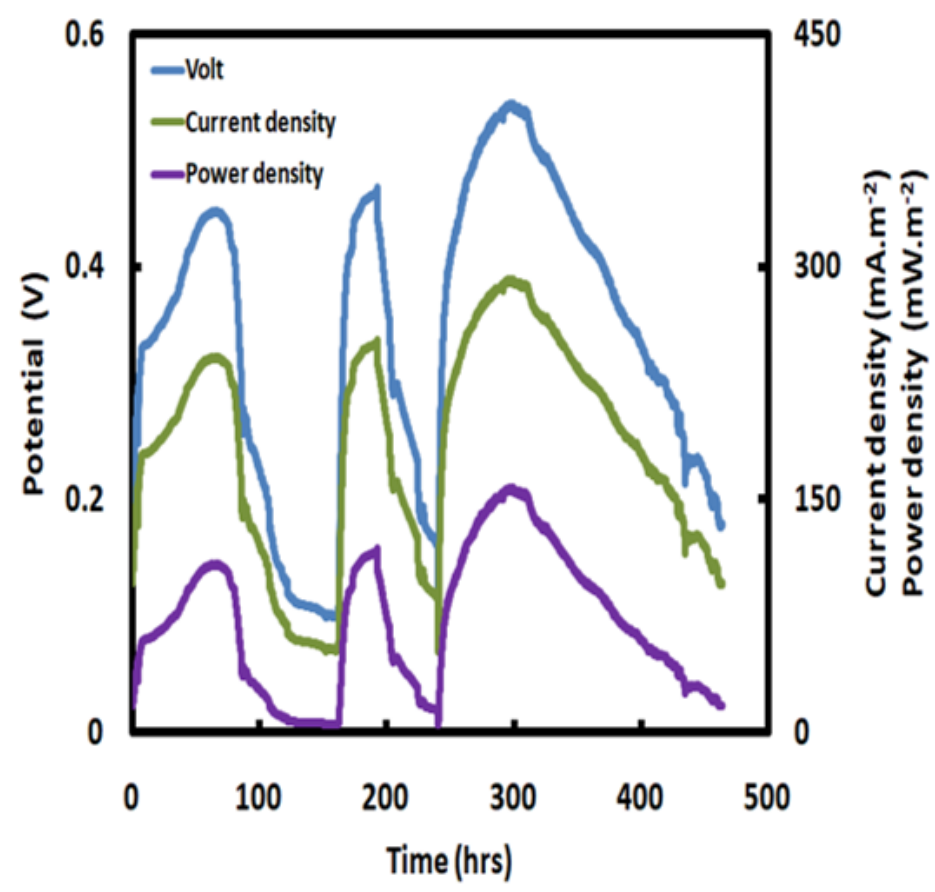

Figure 6

Comparison of voltage generations for Pt/C and NiO-CuO/G alloy catalysts across an external resistance (1000 $\Omega$ ) in ACSCMFCs over the long-term operation for acetate concentration of $2 \mathrm{~g} / \mathrm{L}$. a) Pt/C ACSCMFC performance, b) NiO-CuO/G ACSCMFC performance.

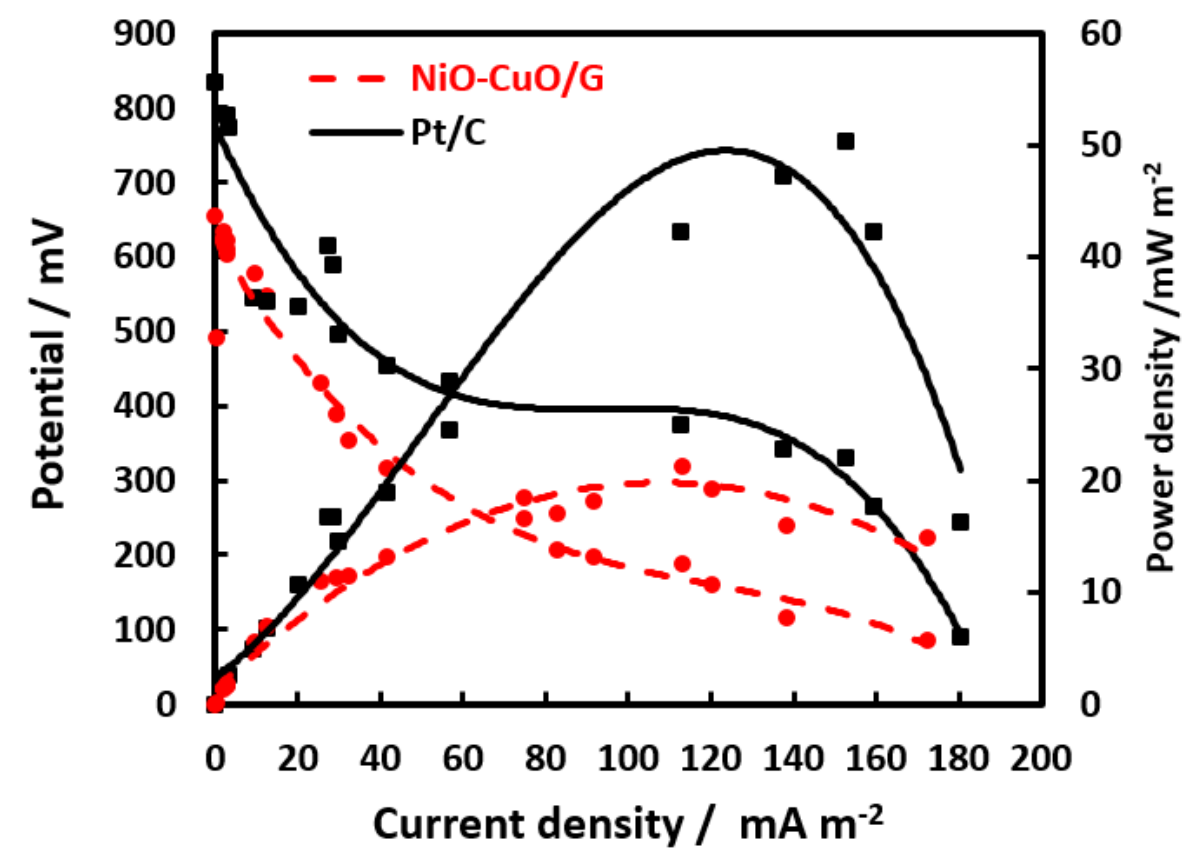

Figure 7

The variation of power density and polarization as function of current density in the ACSCMFCs with the cathodes of Pt/C (blue line), and NiO-CuO/G (dark red line). 
$1 \mathrm{C}$

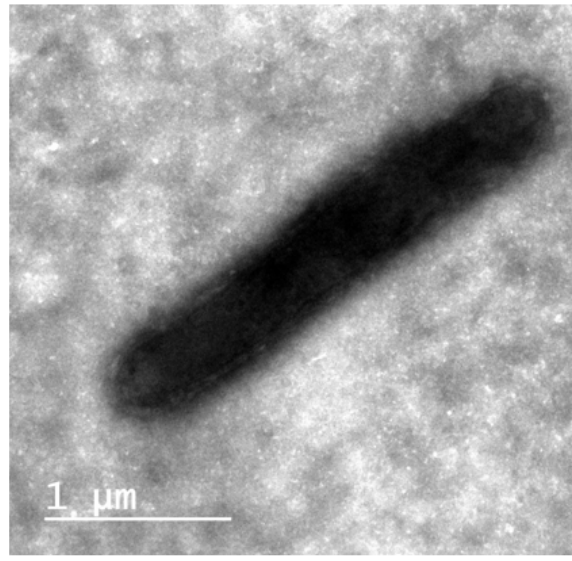

$3 C$

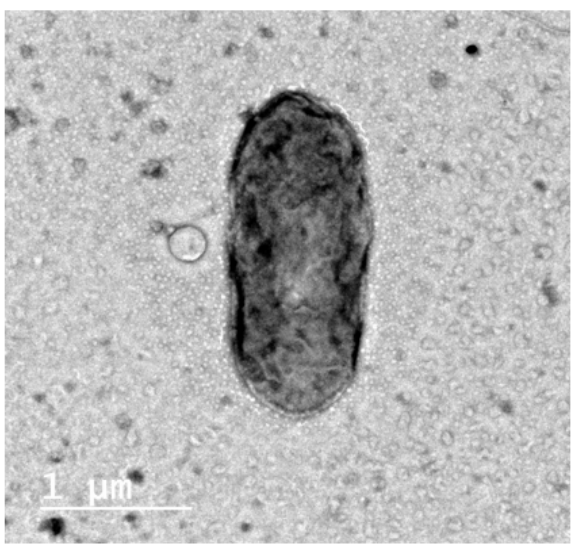

2C

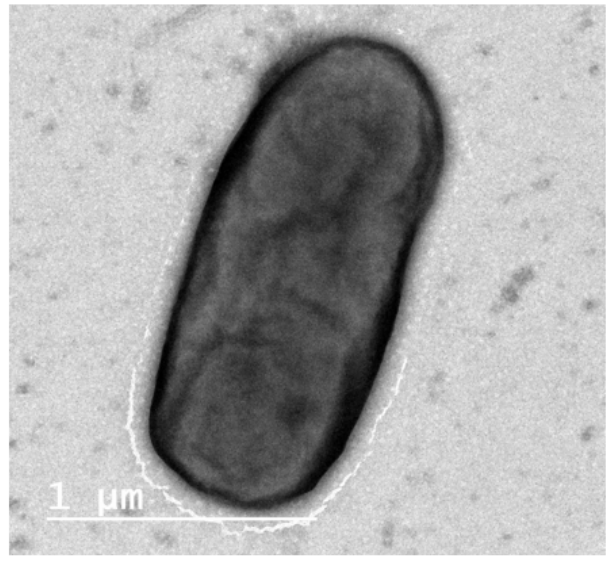

4C

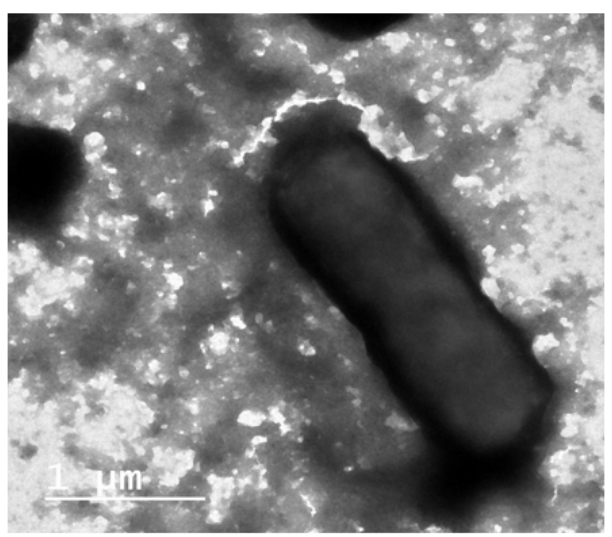

\section{Figure 8}

high-magnification transmission electron micrograph analysis of the isolated bacterial surface layer from anodic biofilm (1C:4C).

\section{Supplementary Files}

This is a list of supplementary files associated with this preprint. Click to download.

- supplementarydata.docx 